\title{
Developing Energy Technology Course for Undergraduate Engineering Management Study Program in Lake Toba Area with Particular Focus to Sustainable Energy Systems in Development Context
}

\author{
Yosef Manik ${ }^{1, *}$, Rizal Sinaga ${ }^{1}$, and Hadi Saragi ${ }^{1}$ \\ ${ }^{1}$ Engineering Management Study Program, Institut Teknologi Del, Laguboti - Indonesia
}

\begin{abstract}
Undergraduate Engineering Management Study Program of Institut Teknologi Del is one of the pioneers for its field in Indonesia. Located in Lake Toba Area, this study program has a miss ion to provide high quality Engineering Management education that produces globally competitive graduates who in turn will contribute to local development. Framing the Energy Technology course - one of the core subjects in Engineering Management Body of Knowledge — in the context of sustainable development of Lake Toba Area is very essential. Thus, one particular focus in this course is sustainable energy systems in local development context that incorporates identification and analysis of locally available energy resources. In this paper we present our experience in designing such course. In this work, we introduce the domains that shape the Engineering Management Body of Knowledge. Then, we explain the results of our evaluation on the key considerations to meet the rapidly changing needs of society in local context. Later, we present the framework of the learning outcomes and the syllabus as a result of mapping the road map with the requirement. At the end, the summary from the first two semesters of delivering this course in academic year 2015/2016 and 2016/2017 are reported.
\end{abstract}

\section{Introduction}

The Undergraduate Engineering Management Study Program (UEMSP) in Institut Teknologi Del is one of the pioneers for its field in Indonesia. Founded in 2014, UEMSP is currently having a student body of 210 students. The core objective of UEMSP is to prepare students for careers that involve the complex interplay of technology, data, organizations and economics. Through an integrated curriculum, the Engineering Management bachelor's degree program combines a strong engineering core with training in data analysis and visualization, process and project management, engineering design, systems integration, and managerial economics.

The interdisciplinary of UEMSP faculties includes those with expertise in wide range of topics as engineering economics; decision and risk analysis; economic management and marketing; and management of people and organizations that affect technology. The program is designed to give students the knowledge to measure and evaluate technical, business, and human performance processes in engineering environments. In the required courses, students are expected to develop their perspectives on the core of technology in industry and to gain insight into other management issues critical to leading or managing a technological organization.

Energy Technology Course (ETC) is listed as a compulsory course during sophomore year. This course of 3 credit-hours per week is essentially aimed to provide UEMSP students with strong foundation in scientific and technological factors, as well as the nature of the energy in nature and society. This will enable them to see the big-picture perspective that comes with in the real world. Designing ETC for a non-traditional engineering sub-discipline in the context of developing country is unique and challenging. In this paper, the authors describe the design process, implementations and evaluations of ETC in terms of aims, philosophy, structure and outcomes from some of this initiative.

\section{Methodology for Course Design}

Various models have been presented in the engineering educational literature for the development of course for study programs in engineering. The model suggested here is a simple three-stage model that effectively encapsulates most features inherent in a logical and structured approach to course design that has been adapted from that described by Kruse and Keil [1] and by Dick et al. [2].

Essentially the model identifies the following stages in the design and development of ETC:

Stage 1. Analysis of some Key Considerations

Stage 2. Structuring the Course

Stage 3. Implementation and Evaluations Each stage has a set of inputs which must be evaluated and then analyzed to produce the output from that stage. 
However, the process is not linear as this would suggest but is highly iterative with multiple secondary interactions and revisions before moving on to the next stage. The process is illustrated in Fig. 1.

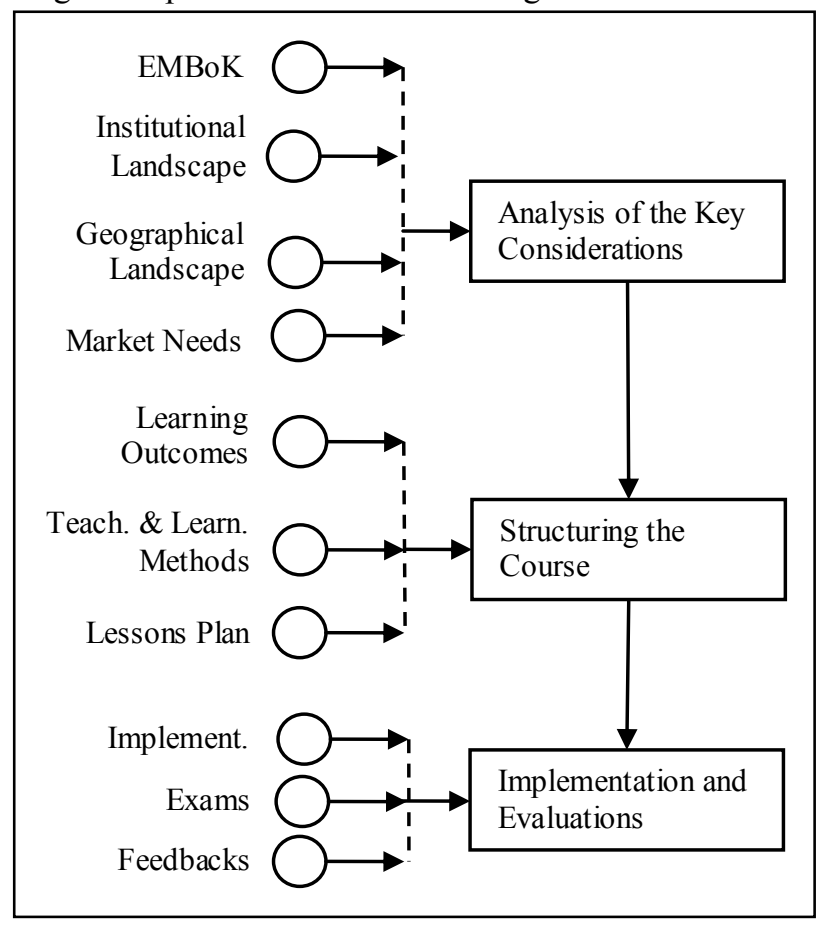

Figure 1. Course Design Process

\section{Key Considerations of Course Design}

\subsection{Engineering Management Body of Knowledge (EMBOK)}

Engineering Management (EM) is a relatively young discipline which combines a knowledge of both academic and practice topics. Over the last 25 years, there have been a number of articles which analysed EM curricula and helped define an EMBoK. The most prominent of these authors was Kocaoglu $[3,4]$ and Farr [5] who analysed virtually all the EM related undergraduate and graduate programs using a consistent set of categories.

The ABET Engineering Criteria [6] requires that the Engineering Management curriculum must prepare the graduate "to understand the engineering relationships between the management tasks of planning, organization, leadership, control, and the human element in production, research, and service organizations; to understand and deal with the stochastic nature of management systems. The curriculum must also prepare graduates to integrate management systems into a series of different technological environments."

Simply put, in order to support the core competencies for EM, the following sets of courses must be provided:

[1] Science and Engineering domain: Physics, Chemistry, Thermodynamics, Energy, etc.

[2] Quantitative domain: Math, Statistics, Operation Research, Programming, Simulations, etc.
[3] Qualitative Conceptual domain: Management Theory, System Thinking, Organizational Behaviours, Leadership, Entrepreneurship, etc.

[4] Functional Technical Management domain: Logistics, Quality Management, Marketing, etc.

[5] Project-related domain: Engineering Design, Project Management, Capstone, Internship, etc.

[6] Finance and Accounting domain: Engineering Economics, Cost Accounting, etc.

It is clear that in order to comply with EMBoK, UEMSP shall equip its curricula with energy course, which is an essential element of its core competence in terms of Science and Engineering domain.

\subsection{Institutional Landscape: Institut Teknologi Del}

Institut Teknologi Del (IT Del) is the home institution for UEMSP. IT Del was founded in 2001 by Gen. (ret.) Luhut Pandjaitan as a polytechnic consisting of three study programs that mainly focus in informatics. The campus is located in Laguboti town $\left(2^{\circ} 23^{\prime} 08.6^{\prime \prime} \mathrm{N}\right.$ $\left.99^{\circ} 08^{\prime} 53.7^{\prime \prime E}\right)$, a remote area in Toba Highland $(255 \mathrm{~km}$ away from Medan, the provincial capital of North Sumatra), just on the shore of Lake Toba. The initial goal of establishing IT Del was to provide access to quality education for outstanding students who face economic hardship in remote areas of Toba. In 2013 it transformed into institute of technology with eight study programs, including UEMSP.

At the moment, IT Del has about 1,500 students. Being a boarding school, all of these students live in the campus dormitory. Although admission is now open nationwide, demographically the student body is dominated by those come from around Lake Toba Area. As a matter of fact, generally they have not been exposed to urban life. Nevertheless, they have high motivation and sufficient intellectual capacity because they have passed a rigorous selection process. With dynamic and motivated student characters, it is appropriate that course materials are designed in a challenging, full of novelty and future-oriented forms.

\subsection{Geographical Landscape: Lake Toba Area}

Lake Toba Area is the area of which IT Del is located and from which most of the students originated. Physically, the area of Lake Toba is an area that is located around Lake Toba with delineation of boundaries based on the delineation of the Water Catchment Area. Lake Toba is the largest freshwater lake in Indonesia and Southeast Asia $\left(90 \times 30 \mathrm{~km}^{2}\right)$ that contains a lot of potential in many facets. In the context of geology, the Toba Caldera and its paroxysmal eruption 74,000 years ago have gained scientific notoriety for the past century [2]. In the context of socio-cultural, Lake Toba is a heritage to the civilization history of Batak tribe, one of the largest ethnic groups in Indonesia. In the context of economics, this lake is the source of livelihood of people living in its surrounding, such as fresh water source, 
irrigations, aquaculture, hydropower, and geothermal [8].

Understanding of the physical potential of Lake Toba Area, especially the potential of energy generation from hydropower and geothermal, is a huge plus in designing a contextual ETC material.

\subsection{Market Needs: Trends and Changes in the Global Energy Business}

Another consideration in designing ETC is the trends and changes in the global energy business. The renewable energy industry is growing rapidly amidst rising concerns about oil depletion and climate change [9]. Renewable energy is seen by many as part of the appropriate response to these concerns and some national Governments have put programs in place to support the wider use of sustainable energy systems.

Traditional engineering study programs nowadays are not trained to use these renewable energy technologies and most are not aware of the principles of sustainability. There is therefore an urgent need to develop and implement new courses that prepare engineers, scientists and energy planners to work with renewables to produce sustainable energy generation systems.

\section{Structuring the Course}

\subsection{Learning Outcomes}

Embarking from the key considerations discussed earlier, we agreed to define the learning outcomes, the understanding and competence of which the students will have after completing the ETC, as follow:

[1] Students understand the principles of energy flow in the biosphere, the principles of photosynthetic and global primary production, and the techniques in energy provision during the pre-industrial and industrial era.

[2] Students understand the basic concepts in chemistry and properties of hydrocarbon fuels, the techniques in extraction of selected fossil fuels, the sciences in combustion of selected fossil fuels, and the principles of selected utilization of fossil fuels in society.

[3] Students are able to develop understanding and construct arguments on selected topics through writing up a connection paper.

[4] Students understand the principles and emerging trends of renewable energies and the economics of energy in terms of cost and environmental issues

\subsection{Teaching- and Learning Methods}

This course is design for students at the sophomore year. As prerequisite, they need to have passed the Fundamental Physics (8 credit-hours) and Fundamental
Chemistry (4 credit-hours). Thermodynamics course (3 credit-hours) is set as co-requisites.

In general, this course is delivered through classroom lecture. Presentation slides and whiteboards are used as the media. All electronic course materials are provided through a web-based academic information system <cis.del.ac.id> which can be downloaded by students at any time.

The lectures are provided by three faculties as a team, whose specific expertise is given in Table 1 .

Table 1. Instructors for ETC

\begin{tabular}{|c|c|c|}
\hline $\begin{array}{l}\text { Instruc } \\
\text { t-or }\end{array}$ & $\begin{array}{l}\text { Highest academic } \\
\text { degree }\end{array}$ & Field of expertise \\
\hline$\# 1$ & $\mathrm{PhD}$ & $\begin{array}{l}\text { Sustainability, bioenergy, } \\
\text { combustion technology }\end{array}$ \\
\hline \#2 & Masters & $\begin{array}{l}\text { Physics, geothermal, } \\
\text { thermodynamics }\end{array}$ \\
\hline \#3 & Masters & $\begin{array}{l}\text { Electrical power } \\
\text { engineering }\end{array}$ \\
\hline
\end{tabular}

In the middle of the semester, two field visits are arranged. These field visits are intended to give students insight into the energy generation process in its true form. The visits are held interchangeably at energy plants located within Lake Toba Area, such as Siguragura Hydropower, Labuhan Angin Steam Power Plant, Sibayak Geothermal Plant, or Sarulla Geothermal Plant. As deliverable outcomes from the visits, students are assigned to write connecting papers about the findings and lesson learned, and to present the papers before the faculty panels.

A visiting lecture is also held. This lecture is delivered a practitioner, a government officer, or a decision maker in the field of energy business. Having a specialist in this particular subject area will help students to interact with the real actors in the energy business. It also benefits them because closer links can be forged with the expert's home institution in case they need it for internship or future employment.

Main reference for ETS are "Energy: Beginners' Guide" [10] and "Energy in the Nature and Society: General Energetics of Complex Systems" [11], both published by MIT press. Vaclav Smil is Distinguished Professor Emeritus at the University of Manitoba. He is a very productive author in the fields of energy, environmental and population change, food production and nutrition, technical innovation, risk assessment, and related public policy that Bill Gates wrote on his website in 2013:

"[...] there is no author whose books I look forward to more than Vaclav Smil."

In these two books, systematic and exhaustive analysis of all the major energy sources, storages, flows, and conversions that have shaped the evolution of the biosphere and civilization are provided, so that we found it useful as the reference.

\subsection{Lessons Plan}

After the learning outcomes have been determined, the teaching- and learning method have been defined; the 
next step is to select the content and to organize in a manner that will facilitate the learning of it by the student. At this stage it is necessary to identify the elements of the curriculum that can serve as organizing threads, which, in engineering, are often concepts, percepts and skills. Learning is designed to take place in 7 consecutive weeks, followed by mid-term exam, and continued to another 7 consecutive weeks, followed by final exam. All learning materials are presented as a series of topics in 14 classes, the sequence of which is given Table 2 .

Table 2. ETC Structure

\begin{tabular}{|c|c|c|}
\hline Week & Topic & Sub-topic \\
\hline 1 & $\begin{array}{l}\text { Fundamentals } \\
\text { and outlook }\end{array}$ & $\begin{array}{l}\text { - Science of energy: origins } \\
\text { and abstracts } \\
\text { - Fundamental concepts: } \\
\text { energies, conversion, } \\
\text { effic iencies }\end{array}$ \\
\hline 2 & \multicolumn{2}{|c|}{ Recitations on selected energy conversion problems } \\
\hline 3 & $\begin{array}{l}\text { Energy in the } \\
\text { biosphere (1) }\end{array}$ & $\begin{array}{l}\text { - Sun: the star and its radiation } \\
\text { - Hydrosphere and atmosphere: } \\
\text { thermal and mass fluxes }\end{array}$ \\
\hline 4 & $\begin{array}{l}\text { Energy in the } \\
\text { biosphere (2) }\end{array}$ & $\begin{array}{l}\text { - Water and air in motion: } \\
\text { kinetic fluxes } \\
\text { - Geo-energetics: heat, plate } \\
\text { tectonics, volcanoes, } \\
\text { earthquake }\end{array}$ \\
\hline 5 & $\begin{array}{l}\text { Bioenergetics of } \\
\text { primary } \\
\text { production }\end{array}$ & $\begin{array}{l}\text { - } \text { Photosynthetic pathways } \\
\text { - Global primary production } \\
\text { - Cropping intens ification }\end{array}$ \\
\hline 6 & Fossil fuels (1) & $\begin{array}{l}\text { - Hydrocarbon fuel chemistry } \\
\text { and properties } \\
\text { - Extraction and distribution }\end{array}$ \\
\hline 7 & \multicolumn{2}{|c|}{ Field visit to energy plants } \\
\hline \multicolumn{3}{|c|}{---------------- Mid-term Exam ---------------- } \\
\hline 8 & Fossil fuels (2) & - Combustion and applications \\
\hline 9 & Fossil fuels (3) & $\begin{array}{l}\text { Utilization in prime movers } \\
\text { and electricity generation }\end{array}$ \\
\hline 10 & \multicolumn{2}{|c|}{ Recitations on fossil fuel problems } \\
\hline 11 & Renewables (1) & $\begin{array}{l}\text { - Photovoltaic } \\
\text { - Hydropower }\end{array}$ \\
\hline 12 & Renewables (2) & $\begin{array}{l}\text { - Geothermal } \\
\text { - Biomass } \\
\end{array}$ \\
\hline 13 & \multicolumn{2}{|l|}{ Visiting lecture } \\
\hline 14 & $\begin{array}{l}\text { Energy } \\
\text { economics }\end{array}$ & $\begin{array}{l}\text { - Energy cost and valuation } \\
\text { - Externality analysis }\end{array}$ \\
\hline \multicolumn{3}{|c|}{---------------- Final Exam ---------------- } \\
\hline
\end{tabular}

The grading scheme is as follow:
[1] Assignments and quizzes
$: 10 \%$
[2] Connecting paper
$: 15 \%$
[3] Post field visit presentation
$: 15 \%$
[4] Mid-term exam
$: 30 \%$
[5] Final exam
$: 30 \%$

In order to pass the course, the student must earn not least than $30 \%$ of the weighted score average.

\section{Implementation and Evaluations}

ETS has been implemented in two consecutive academic years: odd semester 2015/2016 and odd semester $2016 / 2017$. The numbers of participating students for the academic year 2015/2016 and 2016/2017 are 30 and 60, respectively. All students are sophomore from Engineering Management major, with age range of 19 20 years old.

Participation and enthusiasms of the students were very high. This was reflected in their attendance and participation in each class and also in the interaction among them in group discussions. Classes were held according to lessons plan, including field visits and guest lecture. For the field visits, the students are brought to Labuhan Angin steam power plant and Sigura-gura hydropower. Guest lecture was given by practitioners in micro-hydropower. For the academic year 2015/2016, $100 \%$ of the students passed the exams. However, for the academic year $2015 / 2016$, only $77 \%$ did.

The end-of-semester surveys show that student satisfaction level is high in both academic years. Some feedback suggests that field visits are a great help for them to understand what is really happening in the real world in the area of energy conversion and generation. As for things that still need to be improved, the survey suggests, is the exercise in solving quantitative analysis problems.

In the coming semesters such a pattern will continue while improving the things that still need to be improved. For this, the instructors will continue to improve their capacity and to extend collaboration with external partners who are expected to help improving the quality of this course.

\section{References}

1. K. Kruse, \& J. Keil, , Technology-based training: The art and science of design, development, and delivery. San Francisco: Jossey-Bass (2000)

2. W. O. Dick, L. Carey, and J. O. Carey, The systematic design of instruction. Boston: Allyn \& Bacon (2004)

3. D.F. Kocaoglu, The Emergence of Engineering Management Discipline, ASEE Conference Proceedings pp.240-247 (1986)

4. D.F. Kocaoglu, Education for Leadership in Management of Engineering and Technology pp.7883 IEEE (1992)

5. J. Farr, and B.A. Bowman, Engineering Management Programs: Contemporary and Future Issues, Eng. Mgt. J., 11 (1999)

6. ABET Engineering Accreditation Commission, 2015-2016 Criteria for Accrediting Engineering Programs pp.11, (2014)

7. C.A. Chesner, Quaternary International. 258, pp.518 (2012)

8. H. Moedjodo, P. Simanjuntak, P. Hehanussa, and Lufiandi. Lake Toba: Experience and Lessons Learned Brief. Lake Toba Heritage Foundation (2003)

9. REN21, Renewables 2015 Global Status Report Paris: REN21 Secretariat (2015) 
10. V. Smil, Energy: Beginners' Guide. MIT Press (2006)
11. V. Smil, Energy in Nature and Society: General Energetics of Complex Systems. MIT Press (2008) 